\title{
Aplikasi Imbuhan Tepung Daun Sirih (Piper betle Linn) dalam Pakan pada Ayam Joper
}

\section{Application of Betel Leaf Meal (Piper betle Linn) in Feed on Joper Chicken}

\author{
M. R. Shaffira ${ }^{1}$, A. A. Candra ${ }^{1^{*}}$, dan Y. Priabudiman ${ }^{1}$ \\ ${ }^{1}$ Jurusan Peternakan, Politeknik Negeri Lampung \\ *E-mail : adicandra@polinela.ac.id
}

\begin{abstract}
Along with consumer demands for safe and healthy animal protein source products, it is necessary to conduct research using herbal plants which are expected to have the same benefits as antibiotics. One of the medicinal plants that are well known in Indonesia is betel leaf (Piper betle Linn.). This plant has properties that are almost the same as antibiotics. Betel leaf is generally known to the public as a traditional medicinal ingredient, betel leaf also has antibacterial properties due to the flavonoids, saponins, and tannins in the betel leaf. Super free-range chickens are included in the non-racial or domestic chicken, which is a cross between a male local chicken and a female chicken. Growth is faster than native chickens, easily adapts to the environment, and has a taste that is no different from native chickens. Technology is needed in the maintenance of super Javanese chickens to produce safe products but has an impact on high productivity in super Javanese chickens. The purpose of this study was to determine the hematological status and carcass quality of Joper chickens which were given the addition of betel leaf flour (Piper betle Linn) as a feed additive. This research was conducted in July - September 2019. The research location was located in the Lampung State Polytechnic cage and laboratory. This study used 100 hens. The parameters tested include analysis of blood components including measurement of hematocrit levels, hemoglobin levels, red blood cell counts, white blood cell counts, and carcass quality including carcass percentage and cooking losses. The results of this study indicate that the administration of betel leaf flour (Piper betle Linn) at various doses did not cause a difference in hemoglobin, erythrocytes, leukocytes and hematocrit and the addition of betel leaf flour (Piper betle Linn) to hens that were kept for 60 days affected the percentage of carcasses in giving $1 \%-2.5 \%$ and does not affect cooking losses at giving $1 \%$ to $2.5 \%$ betel leaf flour (Piper betle Linn)
\end{abstract}

Keywords: feed, Joper, Piper betle Linn

Diterima: 27 Agustus 2020, disetujui 30 September 2020

\section{PENDAHULUAN}

Ayam jawa super (joper) termasuk dalam golongan ayam bukan ras atau ayam buras, yang merupakan persilangan antara ayam lokal jantan dengan ayam ras betina (Iskandar, 2006). Pertumbuhan lebih cepat dari pada ayam kampung, mudah beradaptasi dengan lingkungan serta memiliki citarasa yang tidak berbeda dengan ayam kampung (Kaleka, 2015).

Seiring dengan tuntutan konsumen akan produk sumber protein hewani yang aman dan sehat perlu dilakukan penelitian menggunakan tanaman herbal yang diharapkan mempunyai manfaat sama dengan antibiotik. Berbagai tanaman obat digunakan oleh masyarakat. Penelitian tanaman herbal juga telah 
dilakukan beberapa diantaranya adalah menggunakan temulawak sebagai pemacu pertumbuhan pada broiler (Candra et al., 2017; Candra dan Putri, 2020). Salah satu tanaman obat yang sudah dikenal di Indonesia adalah daun sirih (Piper betle Linn.). Tanaman ini mempunyai khasiat yang hampir sama dengan antibiotik. Daun sirih secara umum telah dikenal masyarakat sebagai bahan obat tradisional, daun sirih juga mempunyai kemampuan sebagai antibakteri (Sastroamidjojo, 1997) di dalam daun sirih juga terdapat flavanoid, saponin, dan tannin. Saponin dan tannin bersifat sebagai antiseptik pada luka permukaan, bekerja sebagai bakteriostatik yang biasanya digunakan untuk infeksi pada kulit, mukosa dan melawan infeksi pada luka (Mursito, 2002). Laporan tentang penggunaan sirih dalam dunia peternakan diantaranya dilaporkan oleh (Moeljanto, 2003). Penambahan tepung daun sirih sebagai imbuhan pakan diharapkan dapat merangsang pertumbuhan atau merangsang produksi, hal ini sesuai dengan Aqsa et al. (2016), imbuhan pakan adalah yang umum digunakan dalam meramu pakan ternak, penambahan bahan biasanya hanya dalam jumlah sedikit, misalnya bahan konsentrat, bahan suplemen dan premix. Maksud dari penambahan adalah untuk merangsang pertumbuhan atau merangsang produksi.

Tujuan penelitian ini adalah untuk mengetahui status hematologis dan kualitas karkas ayam joper yang diberikan penambahan tepung daun sirih (Piper betle Linn) sebagai imbuhan pakan.

\section{METODE PENELITIAN}

Penelitian ini dilaksanakan di kandang dan laboratorium Politeknik Negeri Lampung. Penelitian ini menggunakan 100 ekor ayam joper yang dipelihara sejak umur 1 hari sampai umur 8 minggu. Pengambilan sampel darah dilakukan pada 2 minggu dengan cara mengambil sampel ayam dari masing-masing satuan percobaan sebanyak 5 kali, jadi total sampel sebanyak 25. Ransum yang digunakan dalam penelitian mengandung energi metabolis $2.913,28 \mathrm{kkal} / \mathrm{kg}$ dan protein $21,38 \%$ yang digunakan sebagai kontrol, sedangkan perlakuan yang dicampur dengan tepung daun sirih sebesar $1 \% ; 1.5 \% ; 2 \% ; 2.5 \%$

Daun sirih segar yang telah dicuci bersih dipotong kecil-kecil berukuran $2-5 \mathrm{~cm}$ lalu dikeringkan dibawah sinar matahari selama 2 - 3 hari. Untuk mengoptimalkan proses pengeringan, daun sirih yang telah dipotong dikeringkan di dalam oven selama 24 jam dengan suhu 40oC. Setelah kering, potongan daun sirih tersebut kemudian digiling menggunakan blender lalu disaring dengan menggunakan ayakan.

Parameter yang diuji antara lain adalah Analisis komponen darah meliputi pengukuran kadar hematokrit, kadar hemoglobin, jumlah sel darah merah, jumlah sel darah putih dan kualitas karkas meliputi persentase karkas dan susut masak. ayam joper yang diambil sampelnya menggunakan ayam yang sama dan jumlah sampelnya yaitu tiap perlakuan 4 sampel dan pengambilan persentase karkas dilakukan diakhir pemeliharaan dan dilakukan pengukusan pada bagian dada untuk mengetahui susut masak.

Data yang diperoleh dari hasil pengukuran dianalisis dengan analisis varians berdasarkan Rancangan Acak Lengkap (RAL) 5x4 yaitu 5 perlakuan dan 4 ulangan. Pengambilan sampel darah pertama dilakukan satu minggu setelah ayam masuk kemudian pemeriksaan darah selanjutnya dilakukan dua minggu setelah pengambilan darah sebelumnya. Apabila perlakuan berpengaruh nyata dilanjutkan dengan Uji Duncan (Gaspersz, 1991).

\section{HASIL DAN PEMBAHASAN \\ Hematologis}

Data hematologis ayam joper yang dipelihara selama 60 hari dengan penambahan tepung daun sirih (Piper betle Linn) disajikan pada tabel 1. 
Tabel 1. Gambaran hematologis ayam joper dengan pemberian tepung daun sirih

\begin{tabular}{lccccc}
\hline \multicolumn{1}{c}{ Variabel } & kontrol & $1 \%$ TDS & $1,5 \%$ TDS & $2 \%$ TDS & $2,5 \%$ TDS \\
\hline Hemaglobin $(\mathrm{g} / \mathrm{dL})$ & 10,23 & 12,15 & 11,15 & 12,18 & 11,78 \\
Erirosit $(\mu \mathrm{L})$ & 2,23 & 2,6 & 2,48 & 2,6 & 2,55 \\
Leukosit $(\mu \mathrm{L})$ & 3,7 & 4,5 & 4,25 & 4,63 & 4,4 \\
Hematokrit $(\%)$ & 29,5 & 34,75 & 32,25 & 35 & 32,75 \\
\hline
\end{tabular}

Hasil penelitian pada tabel 1 menunjukkan bahwa pemberian tepung daun sirih (Piper betle Linn) pada ayam joper yaitu kontrol (10,23 g/dL), $1 \%$ TDS (12,15 g/dL), 1,5\% TDS (11,15 g/dL), 2\% TDS (12,18 g/dL) dan 2,5\% TDS (11,78 g/dL). Dapat dikatakan bahwa yang tidak diberi tepung daun sirih (Piper betle Linn) yaitu lebih rendah jika dibandingkan dengan yang diberikan perlakuan. Walaupun antar perlakuan terlihat ada perbedaan tetapi setelah dilakukan analisis statistik dinyatakan bahwa antar perlakuan tidak berbeda nyata $(\mathrm{P}>0,05)$ dan masih dalam kisaran yang normal. Pemberian perlakuan tepung daun sirih (Piper betle Linn) sampai dosis 2,5 \% masih dalam keadaan normal yaitu dengan kisaran 10,23 - 11,78. (Darmawan et al., 2017) mengemukakan bahwa kisaran normal kadar hemoglobin dalam darah ayam berada pada kisaran $7,0-13,0 \mathrm{~g} / 100 \mathrm{ml}$.

Kadar hemoglobin pada ayam dipengaruhi oleh faktor genetik, umur hewan, jenis kelamin, spesies, lingkungan, musim, nutrisi, ada tidaknya kerusakan eritrosit, waktu pengambilan sampel, status kesehatan, jenis antikoagulan yang dipakai dan metode yang digunakan (Reron et al., 2016).

Eritrosit adalah sel darah merah yang merupakan salah satu komponen dalam darah yang berfungsi sebagai pegangkut oksigen dalam darah untuk distribusikan keseluruh organ tubuh. Eritrosit berfungsi sebagai media pengangkut oksigen $(\mathrm{O} 2)$ dari paru-paru ke jaringan tubuh dan karbondioksida $(\mathrm{CO} 2)$ dari jaringan tubuh ke paru-paru oleh hemoglobin.

Hasil penelitian menunjukkan bahwa pemberian tepung daun sirih (Piper betle Linn) masih dalam keadaan normal yaitu dengan kisaran 2.23 - 2.6 $\mu \mathrm{L}$. Darmawan et al. (2017) mengemukakan bahwa kisaran normal jumlah eritrosit dalam darah ayam berada pada kisaran 2,3-3,5 x 10/mm. Jika dibandingkan jumlah eritrosit pada ayam yang tidak diberi perlakuan lebih rendah dibandingkan yang diberi perlakuan tepung daun sirih (Piper betle Linn) yaitu pada angka kontrol $(2,23 \mu \mathrm{L}), 1 \%$ TDS $(2,6 \mu \mathrm{L}), 1,5 \%$ TDS $(2,48 \mu \mathrm{L})$, $2 \%$ TDS $(2,6 \mu \mathrm{L})$ dan 2,5\% TDS $(2,55)$ tetapi setelah dilakukan analisis statistic menunjukan bahwa antar perlakuan tidak berbeda nyata $(\mathrm{P}>0,05)$.

Jumlah eritrosit dipengaruhi oleh bangsa dan jenis ternak, jenis kelamin, umur, kondisi tubuh variasi harian, kondisi nutrisi, aktivitas fisik, temperature lingkungan dan keadaan stress (Reece et al., 2015). Jumlah eritrosit dan kadar hemoglobin akan bertambah bila kandungan oksigen dalam darah rendah. Kandungan oksigen yang menstimulir penambahan jumlah eritrosit dan kadar hemoglobin, karena ternak yang banyak melakukan aktivitas akan memiliki jumlah eritrosit yang banyak pula, karena ternak akan mengonsumsi banyak oksigen.

Leukosit merupakan unit yang aktif dari sistem pertahanan tubuh dengan menyediakan pertahanan yang cepat dan kuat terhadap setiap agen infeksi. Umumnya leukosit digunakan untuk mengetahui adanya infeksi atau tidak jika jumlahnya diatas atau dibawah kisaran normal. Berdasarkan hasil penelitian ini diperoleh bahwa kadar leukosit pada ayam joper yang tidak diberikan tepung daun sirih (Piper betle Linn) berada dibawah dari ayam - ayam perlakuan, yaitu yang diberikan perlakuan tepung daun sirih (Piper betle Linn) yaitu $1 \%-2,5 \%$. namun setelah di uji menggunakan analisis statistik yaitu antar perlakuan tidak berbeda nyata $(\mathrm{P}>0,05)$.

Leukosit antar perlakuan mengalami peningkatan jika dibandingkan dengan kontrol yaitu pada 3.7 $4.63 \mu 1$, dimana jumlah tersebut berada jauh di atas nilai normal. Jumlah leukosit normal pada ayam kampung berada pada kisaran $20.000-30.000 / \mathrm{mm}^{3}$ (Reece et al., 2015). Hal ini dimungkinkan disebabkan 
Shaffira et al.: Aplikasi Imbuhan Tepung Daun Sirih (Piper Betle Linn) dalam Pakan pada Ayam Joper /Peterpan 2 (1): 16-21

karena ayam mengalami stress panas. Dalam kondisi seperti ini ayam menjadi mudah terinfeksi oleh bibit penyakit.

Nilai hematokrit atau packed cell volume adalah suatu istilah yang artinya persentase (berdasar volume) dari darah yang terdiri dari sel darah merah. Hasil penelitian menunjukkan bahwa pemberian tepung daun sirih (Piper betle Linn) yang dihasilkan yaitu kontrol (29,5\%), $1 \%$ TDS (34,75\%), 1,5\% TDS (32,35\%), $2 \%$ TDS (35\%) dan 2,5\% TDS (32,75\%). Hal ini menunjukkan bahwa ayam yang tidak diberi perlakuan tepung daun sirih (Piper betle Linn) lebih rendah nilai hematokritnya jika dibandingkan dengan ayam yang diberi perlakuan. Jumlah hematokrit hasil penelitian ini masih dalam keadaan normal yaitu dengan kisaran 29.5 - 34.75\%. (Reece et al., 2015) hematokrit normal pada kisaran 30 - 33\%.s Pada pemberian 2\% TDS nilai hematokrit paling tinggi. Jumlah nilai hematokrit menurunnya disebabkan oleh stress. Stress karena panas menyebabkan turunnya konsumsi pakan ayam yang menyebabkan menurunnya kadar protein dalam tubuh ayam (Kusnadi, 2006). Peningkatan nilai hematokrit dapat dipengaruhi adanya dehidrasi, stress atau aktivitas yang berlebihan, dan peningkatan suhu lingkungan (Njidda et al., 2014).

\section{Kualitas karkas ayam joper}

Kualitas karkas ayam joper yang diberikan tepung daun sirih sirih (Piper betle Linn) selama 60 hari disajikan pada tabel 2.

Tabel 2. Kualitas karkas ayam joper dengan pemberian tepung daun sirih

\begin{tabular}{lccccc}
\hline \multicolumn{1}{c}{ Variabel } & kontrol & $1 \%$ TDS & $1,5 \%$ TDS & $2 \%$ TDS & $2,5 \%$ TDS \\
\hline Persentase karkas (\%) & $68,83^{\mathrm{a}}$ & $67,06^{\mathrm{b}}$ & $64,34^{\mathrm{c}}$ & $71,66^{\mathrm{d}}$ & $75,13^{\mathrm{e}}$ \\
Susut masak (\%) & 15,31 & 14,44 & 13,77 & 12,22 & 12,44 \\
\hline
\end{tabular}

Persentase karkas merupakan perbandingan antara bobot karkas dengan bobot hidup yang sering digunakan sebagai pendugaan jumlah daging pada unggas. Hasil penelitian pada tabel 2 menunjukkan persentase karkas ayam joper yang dipelihara selama 60 hari yaitu kontrol $(68,83 \%), 1 \%$ TDS $(67,06 \%)$, 1,5\% (64,34\%), $2 \%(71,66 \%)$ dan 2,5\% (75,13\%). Pemberian tepung daun sirih (Piper betle Linn) pada ayam joper yang tidak diberi menunjukkan angka yang persentase karkasnya lebih tinggi jika dibandingkan dengan pemberian perlakuan $1 \%-1,5 \%$, namun lebih rendah jika dibandingkan dengan pemberian $2 \%$ 2,5\%. Setelah dilakukan analisis statistik menggunakan uji lanjut yaitu Anova ternyata terjadi perbedaan yang nyata antara semua perlakuan jika dibandingkan dengan kontrol. Jadi artinya bahwa pemberian tepung daun sirih (Piper betle Linn) pada tahap 1\% - 2,5\% yang mempengaruhi persentase karkas $(\mathrm{P}<0,05)$.

Rataan persentase karkas selama 60 hari penelitian ini berkisar 68,83\% - 75.13\%, angka tersebut berbeda lebih tinggi dengan hasil penelitian Akhadiarto (2010), yakni 57.39\% - 60.08\% dan hasil penelitian Bestari et al. (2005) yakni 61.09 - 66.35\%. Hasil penelitian Pahlepi et al. (2015) bahwa penggunaan ekstrak daun sirih sampai pada level $2 \%$ dalam air minum tidak berpengaruh terhadap bobot akhir, persentase karkas dan lemak abdominal ayam broiler yang dipotong pada umur lima minggu. Jika dibandingkan dengan kontrol pemberian TDS dengan dosis $1 \%$ dan $1.5 \%$ mengalami penurunan, hal ini dimungkinkan karena bobot badan dan konsumsi pakan yang tinggi, persentase karkas juga dipengaruhi jenis kelamin ayam yang dipotong.

Hal ini dimungkinkan disebabkan bahwa pemberian tepung daun sirih sampai $2.5 \%$ dalam pakan memberikan respon peretumbuhan terhadap persentase karkas sehingga persentase karkas joper yang diperoleh berbeda signifikan. Hal ini diduga bahwa penggunaan tepung daun sirih (Piper betle Linn) yang mengandung senyawa flavonoid yang berperan langsung sebagai antibiotik dengan mengganggu fungsi dari mikroorganisme seperti bakteri dan virus, membantu dalam membasmi mikroba pathogen didalam saluran 
pencernaan sehingga zat makanan dapat dimanfaatkan secara efisien sehingga dapat dikonversi menjadi daging.

Susut masak adalah selisih atau perbedaan antara berat sampel daging sebelum dan sesudah dimasak. Nilai susut masak dinyatakan dalam persentase $(\%)$. Hasil penelitian pada susut masak ayam joper yang dipelihara selama 60 hari yaitu kontrol (15,31\%), 1\% TDS (14,44\%), 1,5\% TDS (13,77\%), 2\% TDS $(12,22 \%)$ dan $2,5 \%$ TDS $(12,44 \%)$ angka ini menunjukan bahwa ayam kontrol memiliki nilai susut masak yang tinggi jika dibandingkan dengan pemberian perlakuan, namun setelah dilakukan analisis ragam dinyatakan bahwa antar perlakuan tidak berbeda nyata $(\mathrm{P}>0,05)$ terhadap susut masak (Cooking loss) ayam joper. Hal ini dimungkinkan karena perbedaan berat dada ayam antar kelompok sehingga menghasilkan perbedaan pada susut masak. Soeparno et al., (2018) menyatakan bahwa daging dalam jumlah susut masak rendah mempunyai kualitas yang lebih baik karena kehilangan nutrisi saat perebusan akan lebih sedikit.

\section{KESIMPULAN}

Pemberian tepung daun sirih (Piper betle Linn) pada berbagai dosis tidak menimbulkan perbedaan pada hemoglobin, eritrosit, leukosit dan hematokrit ayam joper yang di pelihara selama 60 hari. Penambahan tepung daun sirih (Piper betle Linn) terhadap ayam joper yang di pelihara selama 60 hari mempengarui persentasi karkas pada pemberian $1 \%$ - 2,5\% dan tidak mempengarui susut masak (cooking loss) pada pemberian $1 \%$ hingga 2,5\% tepung daun sirih (Piper betle Linn)

\section{DAFTAR PUSTAKA}

Akhadiarto, S. 2010. Pengaruh pemberian probiotik temban, biovet dan biolacta terhadap persentase karkas, bobot lemak abdomen dan organ dalam ayam broiler. Jurnal Sains dan Teknologi Indonesia 12(1): 5359.

Aqsa, A. D., Kiramang, K. dan Hidayat, M. N. 2016. Profil organ dalam ayam pedaging (broiler) yang diberi tepung daun sirih (Piper betle linn) sebagai imbuhan pakan. Jurnal Ilmu dan Industri Perternakan 3(1): 148-159.

Bestari, J., Parakkasi, A. dan Akil, S. 2005. Pengaruh pemberian tepung daun mengkudu (Morinda citrifolia Linn) yang direndam air panas terhadap penampilan ayam broiler. Seminar Nasional Teknologi Peternakan Dan Veteriner.

Candra, A. A. dan Putri, D. 2020. Application turmeric as antioxidant for broiler chickens. Journal of Physics: Conference Series 1450(1).

Candra, A. A., Putri, D. D. dan Zairiful, Z. 2017. Perbaikan penampilan produksi ayam pedaging dengan penambahan ekstraksi temulawak pelarut ethanol. Jurnal Penelitian Pertanian Terapan 14(1): 64-69.

Darmawan, I., Suprijatna, E. dan Atmomarsono, U. 2017. Pengaruh frekuensi dan periode pemberian pakan terhadap produksi karkas ayam buras super. Jurnal Peternakan Indonesia 19(1): 10-15.

Gaspersz, V. 1991. Metode Perancangan Percobaan. CV Armico. Bandung.

Iskandar, S. 2006. Tatalaksana Pemeliharaan Ayam Lokal. Balai Penelitian Ternak Cianjur. Bogor.

Kusnadi, E. 2006. Suplementasi vitamin C sebagai penangkal cekaman panas pada ayam broiler. Jurnal Ilmu Ternak dan Veteriner 11: 249-253.

Moeljanto, R. D. dan M. 2003. Khasiat dan Manfaat Daun Sirih, Obat Mujarab dari Masa ke Masa. Penebar 
Shaffira et al.: Aplikasi Imbuhan Tepung Daun Sirih (Piper Betle Linn) dalam Pakan pada Ayam Joper /Peterpan 2 (1): 16-21

Swadaya. Jakarta.

Mursito, B. 2002. Ramuan Tradisional Untuk Kesehatan Anak. Penebar Swadaya. Jakarta.

Njidda, A. A., Shuai, A. A. dan Isidahomen, C. E. 2014. Haematological and Serum Biochemical Indices of Sheep inSemi-Arid Environment of Northern Nigeria. Global Journal of Science Frontier Research: D Agriculture and Veterinary Volume 14(2): 1-9.

Pahlepi, R., Hafid, H. dan Indi, A. 2015. Bobot akhir persentase karkas dan lemak abdominal ayam broiler dengan pemberian ekstrak daun sirih (Piper betle 1.) dalam air minum. Jurnal Ilmu dan Teknologi Peternakan Tropis 2(3).

Reece, W. O., Erickson, H. H., Goff, J. P. dan Uemura, E. E. 2015. Dukes' Physiology Of Domestic Animals, 13th Edition. Wiley-Blackwell. New Jersey. 1-760 hal.

Reron, Z. R. P., Sutrisna, R. dan Siswanto. 2016. Pengaruh ransum berkadar protein kasar berbeda terhadap jumlah eritrosit, kadar hemoglobin dan hematokrit itik jantan. Jurnal Ilmiah Peternakan Terpadu 4(3): $176-181$.

Sastroamidjojo, S. 1997. Obat Asli Indonesia. Dian Rakyat. Jakarta.

Soeparno, Rihastuti, R. A., Indratiningsih dan Triatmojo, S. 2018. Dasar Teknologi Hasil Ternak. UGM Press. Yogyakarta. 132 hal. 